Jurnal Ekonomi Pembangunan, 16 (1), Juni 2015, 85-101

\title{
Effectiveness of Empowerment Micro Enterprise
}

\author{
Isbandriyati Mutmainah \\ Faculty of Economics, Universitas Nusa Bangsa, Bogor \\ Jalan K.H. Sholeh Iskandar km 4. Cimanggu, Tanah Sareal, Kota Bogor, Indonesia. \\ Telp: +62- 0251-7533189; E-mail: isbandriyati@yahoo.com
}

Received: February 2015; Accepted: May 2015

\begin{abstract}
This research aims to analysis the effectiveness of micro enterprise empowerment through P3KUM assistance, with research sites in the Bogor District. Descriptive analysis is used to see micro enterprise characteristic, chi-square test to see micro-business opportunities to get the help, and Wilcoxon Signed Rank Test to see the effectiveness of micro enterprise empowerment. The opportunities for small business long viewed from different business, product type, and type of business. While aid effectiveness viewed from difference between before and after efforts to get aid. A research result shows micro-enterprise opportunities for assistance varies. When viewed from old business, micro-business opportunities for assistance are the same. Meanwhile, if viewed from product type that produce and type of business, micro-business opportunities for assistance are the different. P3KUM aid significantly increase the effectiveness to produce, increase added value, and able to increase capital productivity but able not to increase labor productivity.
\end{abstract}

Keywords: efectivity, empowerment, micro small medium enterprise, P3KUM

JEL Classification: O200, O230, O250, L16

\section{Efektivitas Pemberdayaan Usaha Mikro}

\begin{abstract}
Abstrak
Studi ini bertujuan menganalisis efektivitas pemberdayaan usaha mikro melalui bantuan P3KUM, di Kabupaten Bogor. Penelitian ini menggunakan analisis deskriptif untuk mengamati karakteristik usaha mikro, uji chi-square untuk melihat peluang usaha mikro dalam mendapatkan bantuan, serta Wilcoxon Signed Rank Test untuk melihat efektivitas pemberdayaan usaha mikro. Peluang usaha mikro dilihat dari perbedaan lama usaha, jenis produk utama yang dihasilkan, dan jenis usaha. Sedangkan efektivitas bantuan dilihat dari perbedaan perkembangan usaha antara sebelum dan setelah memanfaatkan bantuan. Hasil studi menunjukkan, peluang usaha mikro untuk mendapatkan bantuan bervariasi. Jika dilihat dari lama usaha, peluang usaha mikro untuk mendapatkan bantuan adalah sama. Sedangkan jika dilihat dari jenis produk utama yang dihasilkan, dan jenis usaha, peluang usaha mikro untuk mendapatkan bantuan adalah berbeda. Bantuan P3KUM secara signifikan mampu meningkatkan efektivitas dalam berproduksi, meningkatkan nilai tambah dan mampu meningkatkan produktivitas modal namun tidak mampu meningkatkan produktivitas tenaga kerja.
\end{abstract}

Kata kunci: efektivitas, pemberdayaan, UMKM, P3KUM

Klasifikasi JEL: O200, O230, O250, L16

\section{Pendahuluan}

Usaha Mikro Kecil Menengah (UMKM) menurut Griffit dan Erbert (1996) dalam Qodri (2006) memiliki tiga peran penting dalam sistem ekonomi negara, yaitu penciptaan lapangan kerja, sumber inovasi serta pendukung usaha besar. Dengan peran penting dari UMKM tersebut, sudah sepantasnya pemerintah tidak 
mengesampingkan mereka sebagai salah satu penggerak kegiatan ekonomi. Perhatian untuk menumbuhkembangkan UMKM setidaknya dilandasi 3 alasan, yaitu UMKM mampu menyerap banyak tenaga kerja, mampu menyerap sumberdaya lokal dan mampu memberi penghasilan sehingga berdampak positif pada upaya pengentasan kemiskinan.

Data ekonomi yang ada menjelaskan bahwa peran UMKM terhadap ketahanan ekonomi nasional semakin menguat. UMKM merupakan populasi terbesar dari pengusaha yang ada. Sejak tahun 1997 saat krisis mulai berlangsung sampai tahun 2012, peran kelompok usaha ini meningkat secara signifikan baik kontribusinya terhadap PDB, investasi, maupun penyerapan tenaga kerja. Menurut data dari Kementerian KUKM (2013), UMKM merupakan proporsi terbesar dari populasi usaha di Indonesia. Sampai tahun 2012 jumlah UKM mencapai 56,53 juta atau $99,99 \%$ dari total pelaku usaha di Indonesia. Hal ini mengindikasikan bahwa UKM merupakan pilar utama perekonomian Indonesia. Komposisi tersebut terdiri dari usaha mikro sebanyak 55,86 juta unit (98,79 persen), usaha kecil sebanyak 0,63 juta unit (1,11 persen), dan usaha menengah sebanyak 0,049 juta unit $(0,09$ persen). Jika dilihat dari kontribusinya, sampai tahun 2012 UMKM mampu memberikan kontribusi terhadap PDB (harga berlaku) sebesar Rp4.869,6 trilyun (59,08 persen), kontribusi terhadap investasi sebesar Rp1.251 trilyun (54,77 persen), kontribusi terhadap penyerapan tenaga kerja sebesar 107,7 juta orang $(97,16$ persen) dan kontribusi terhadap total ekspor sebesar: Rp166,6 trilyun (14,06 persen) .

Sejak krisis ekonomi, hampir semua skala usaha baik mikro, kecil, menengah maupun besar mengalami penurunan populasinya. Di antara ketiga skala usaha tersebut, UMKM yang lebih cepat pulih dibanding usaha skala besar. Pertumbuhan populasi UMKM rata-rata sebesar 4,82 persen per tahun periode 1998-2004, sedangkan usaha skala besar sebesar 4,6 persen pertahun pada periode yang sama.

Kondisi tersebut menunjukkan, posisi UMKM di Indonesia sebenarnya sangat strategis dan dapat menjadi kekuatan ekonomi nasional. Namun di sisi lain peran strategis UMKM secara makro tersebut pada kenyataannya belum selaras dengan kondisi pelaku UMKM itu sendiri. Dengan segala keterbatasannya baik keterbatasan permodalan, teknologi maupun aspek manajemennya menyebabkan di samping daya saing yang terbatas, kesejahteraan pelaku usaha kecil itu sendiri belum terjamin. Tahan menghadapi krisis namun dalam kondisi yang tidak sejahtera. Dalam era perdagangan bebas sekarang, di mana produk-produk pesaing impor membanjiri tanah air, tanpa peran dan bantuan pemerintah maupun pihak-pihak lain, UMKM akan semakin tertinggal jauh. UMKM membutuhkan peran pemerintah dalam upaya peningkatan kinerja dan daya saing dengan upaya pemberdayaan yang berkelanjutan.

Dalam kaitannya dengan pemberdayaan UMKM, dalam UU No.20/2008 tentang UMKM, pemberdayaan didefinisikan sebagai upaya yang dilakukan Pemerintah, Pemerintah Daerah, dunia usaha, dan masyarakat secara sinergis dalam bentuk penumbuhan iklim dan pengembangan usaha terhadap UMKM sehingga mampu tumbuh dan berkembang menjadi usaha yang tangguh dan mandiri. Sedangkan iklim usaha adalah kondisi yang diupayakan Pemerintah dan Pemerintah Daerah untuk memberdayakan UMKM secara sinergis melalui penetapan berbagai peraturan perundangundangan dan kebijakan di berbagai aspek kehidupan ekonomi upaya ini dilakukan agar UMKM memperoleh pemihakan, kepastian, kesempatan, perlindungan, dan dukungan berusaha yang seluas-luasnya.

Secara konseptual pemberdayaan UMKM terutama dapat dilakukan dengan sistim pemberdayaan pelaku UMKM itu sendiri. Keberhasilan pemberdayaan sangat bergantung pada partisipasi UMKM sebagai pelaku maupun stakeholder lain yang turut serta dan berperan dalam pengembangannya. Dalam hal ini lebih banyak menitikberatkan pada metode "bottom up", di mana perencanaan lebih diupayakan menjawab kebutuhan UMKM dan dilakukan secara partisipatif.

Pemberdayaan UMKM bukan hanya untuk meningkatkan kesejahteraan masyarakat bawah, tetapi juga untuk mendukung kesinambungan pertumbuhan ekonomi. Karena tanpa basis yang luas, pertumbuhan ekonomi tidak dapat sustain karena terbatasnya pasar, rendahnya daya beli sebagian besar konsumen dan yang lebih berbahaya adalah meluasnya permasalah- 


\section{Jurnal Ekonomi Pembangunan, 16 (1), Juni 2015, 85-101}

an sosial karena ketimpangan sosial. Jadi, keberhasilan pemberdayaan UMKM merupakan syarat bagi perkembangan perekonomian nasional yang sustainable.

Pemberdayaan UMKM juga menjadi pertahanan yang kokoh di pasar domestik dalam menghadapi persaingan global. Kemampuan unit kelompok usaha ini dalam menguasai pasar lokal akan menjamin pangsa pasar domestik dari serbuan modal besar dari dalam dan luar negeri. Dukungan UMKM juga dapat menentukan kekompetitifan usaha besar di pasar internasional.

Dalam sejarah pembangunan ekonomi Indonesia sebelum krisis, pemberdayaan UMKM hanya dijadikan kajian tanpa ada keinginan yang serius untuk mengimplementasikan, dan upaya pemberdayaan tersebut sangat jauh dari kenyataan, atau dapat disebut juga sebagai upaya setengah hati. Di satu sisi keinginan pemerintah untuk mengembangkan kelompok usaha tersebut dianggap sebagai kebutuhan mendesak untuk mengurangi berbagai bentuk ketimpangan dan tuntutan bagi keharusan partisipasi masyarakat dalam pembangunan.
Namun di sisi lain, berbagai kebijakan pemerintah cenderung menghambat pengembangan ekonomi rakyat dan membuka peluang sebesarbesarnya bagi ekonomi konglomerat melalui berbagai kebijakan proteksi dan fasilitas monopoli melalui kolusi, korupsi dan nepotisme.

Dalam kenyataannya tidak mudah untuk memberdayakan UMKM di Indonesia, karena dalam pertumbuhannya sangat banyak menghadapi kendala dan keterbatasan baik internal maupun eksternal sehingga kurang mampu untuk berkembang. Menurut Rifa ì (2013: 134), faktor internal yang menghambat perkembangan UMKM adalah keterbatasan modal dan akses untuk mendapatkannya, kualitas SDM, lemahnya jaringan dan penetrasi pasar, mentalitas pengusaha dan kurangnya transparansi. Sedangkan faktor eksternalnya antara lain iklim usaha yang kurang kondusif, terbatasnya sarana dan prasarana, pungutan liar, implikasi otonomi daerah, implikasi perdagangan bebas, sifak produk, akses pasar terbatas dan terbatasnya akses informasi. Pendapat Rifa $i$ ini sejalan dengan Sasono (2001:87) yang menyatakan faktor internal yang menghambat perkem-

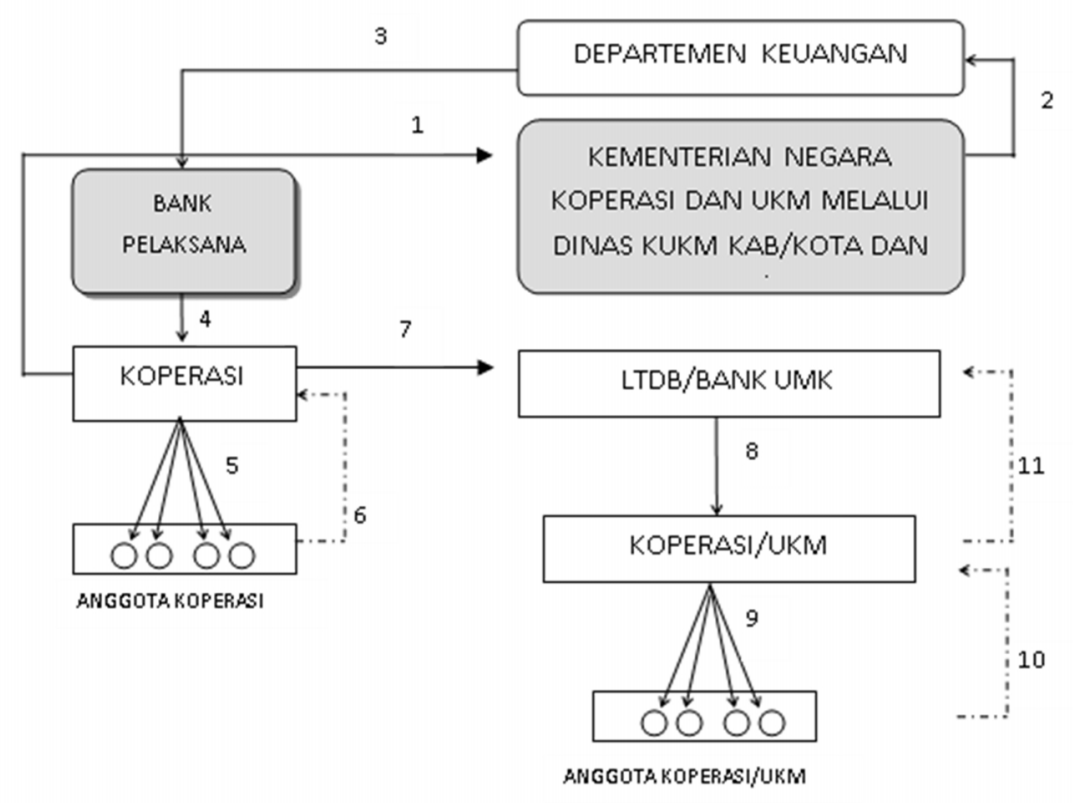

Sumber: Kementerian Koperasi dan UKM RI (2007)

Gambar 1. Alur P3KUM 
bangan UMKM adalah keterbatasan modal, SDM dan jenis produk, sedangkan faktor eksternalnya antara lain pengakuan yang terbatas, akses pasar, nilai tukar produk, pungutan liar dan krisis ekonomi.

Berdasar dua pendapat tersebut dapat ditarik sebuah kesimpulan bahwa kendala yang paling banyak dihadapi UMKM adalah permodalan serta akses untuk mendapatkannya. Walaupun faktor modal sering dapat diatasi, misalnya dalam bentuk pinjaman antarkerabat atau teman, namun dalam tingkat persaingan dan ekspansi, permodalan sering menjadi penghambat utama. Ketika kondisi pasar menawarkan kesempatan atau peluang, dan kreativitas muncul, UMKM sering tidak mampu mengikuti kesempatan-kesempatan tersebut karena kendala modal. Di sisi lain kondisi UMKM biasanya tidak bankable, karakteristik UMKM yang bercirikan keterbatasan dalam administrasi keuangan menyebabkan kelompok usaha tersebut kesulitan untuk mengakses permodalan dari lembaga keuangan. Menurut Syarif dan Budhiningsih (2009:64), kesulitan UMKM mengakses modal dari lembaga keuangan disebabkan karena ketidaksesuaian pendekatan pola dan prosedur lembaga perkresitan formal dengan karakeritik sebagian besar UMKM, khususnya usaha mikro. Padahal diketahui bahwa akses kemudahan perolehan modal sangat berpengaruh terhadap perkembangan UMKM. Semakin mudah akses memperoleh modal baik itu dari pinjaman, investor, maupun bantuan pemerintah akan semakin memudahkan peluang perkembangan UKM (Kristianingsih dan Trimardjono, 2014: 152).

Dalam upaya mengatasi permasalahan permodalan tersebut, pemerintah melalui Kementerian Negara Koperasi dan UKM telah melakukan berbagai upaya peningkatan akses dan memperluas sumber-sumber pembiayaan baik melalui perbankan maupun lembaga keuangan bukan bank. Salah satu upaya yang dilakukan adalah bantuan Program Pembiayaan Produktif Koperasi dan Usaha Mikro (P3KUM) yaitu bantuan permodalan bergulir yang disalurkan kepada usaha mikro melalui lembaga keuangan bukan bank, seperti koperasi, atau koperasi BMT. Usaha mikro menjadi perhatian karena posisi usaha mikro yang sulit memperoleh layanan kredit perbankan karena berbagai kendala baik pada sisi usaha mikro maupun pada sisi perbankan sendiri. Usaha mikro biasanya tidak memiliki manajemen yang bagus, sistem laporan keuangan yang baik dan sumber daya manusia yang terbatas kemampuannya.

Menurut Peraturan Menteri Negara Koperasi dan UKM Nomor 06/Per/M.KUKM/ I/2007 dan nomor 08/Per/M.KUKM/II/2007, yang di maksud dengan P3KUM, adalah rangkaian kegiatan pemerintah yang dilakukan dalam bentuk perkuatan permodalan untuk mengembangkan usaha mikro dan usaha kecil anggota koperasi dengan menggunakan dana bergulir dalam rangka mengurangi kemiskinan dan memperluas kesempatan kerja. Tujuan dari program P3KUM ini secara umum adalah; (1) untuk meningkatkan akses pembiayaan bagi usaha kecil dan mikro melalui penguatan struktur modal koperasi; dan (2) untuk mendukung program pengentasan kemiskinan pemerintah dan meningkatkan kesempatan kerja baru. Jadi dengan program tersebut diharapkan usaha mikro mampu berkembang dan memberikan kontribusi yang tinggi terhadap PDB (pro growth), pengentasan kemiskinan (pro poor) dan penyerapan tenaga kerja (pro job). Mekanisme alur dari P3KUM dapat dilihat dari Gambar 1.

Di kabupaten Bogor sampai tahun 2007 terdapat sekitar 17.312 UMKM yang bergerak pada berbagai macam usaha, seperti jasa, makanan, produk garment, asesoris dan lainlain. Keberadaan UMKM ini perlu dipandang positif, bila dilihat dari keterbatasan pemerintah daerah untuk menyediakan lapangan kerja dan keterbatasan masyarakat Kabupaten Bogor untuk dapat mengakses industri-industri besar. Berbagai bentuk bantuan kepada pelaku UMKM sudah diberikan oleh pemerintah melalui Dinas Perindagkum Kabupaten Bogor, baik bantuan permodalan, bantuan teknis maupun bantuan yang berkaitan dengan aspek manajemen keuangan. Baru sekitar 4.202 unit usaha yang mendapatkan bantuan permodalan dari pemerintah dengan berbagai bentuk bantuan baik melalui koperasi dan lembaga keuangan lainnya dan tidak semuanya berjalan sesuai dengan yang diharapkan, jika dilihat dari masih banyaknya bantuan tersebut yang macet dalam pengembaliannya. Sejumlah 2.180 unit 


\section{Jurnal Ekonomi Pembangunan, 16 (1), Juni 2015, 85-101}

usaha yang lancar dalam pengembalian pinjamannya.

Selama ini pemerintah lebih melihat dari sisi tingkat pengembalian bantuan pinjaman yang lancar sebagai indikator utama keberhasilan suatu program pemberdayaan UMKM. Ketika bantuan pinjaman tersebut dapat dikembalikan tepat waktu, maka dapat dikatakan bahwa program pemberdayaan adalah sudah efektif. Penilaian efektivitas program berdasarkan pada tingkat kelancaran dalam pengembalian bantuan tersebut perlu untuk ditelaah lebih lanjut karena berdasarkan beberapa fakta bahwa penggunaan bantuan tersebut sering tidak tepat sasaran, sehingga upaya pemberdayaan menjadi sia-sia atau pemborosan anggaran semata. Evaluasi yang lebih mendalam dibutuhkan untuk mengetahui seberapa jauh bantuan tersebut dapat meningkatkan kinerja UMKM, seperti peningkatan usaha dan peningkatan produktivitas input. Seperti pendapat dari Tangkilisan dalam Rifa i (2013: 132) bahwa efektivitas suatu program memiliki lima kriteria pengukuran, yaitu produktivitas, kemampuan adapatasi kerja, kepuasan kerja, kemampuan berlaba dan pencarian sumber daya. Dari implementasi P3KUM di Kabupaten Bogor tahun 2007, belum pernah dilakukan kajian untuk mengetahui efektivitas program tersebut terhadap peningkatan usaha mikro yang memanfaatkan bantuan tersebut. Penelitian ini ingin menggali lebih dalam tentang efektivitas pemberdayaan usaha mikro pada program P3KUM di Kabupaten Bogor. Indikator efektivitas dilihat dengan membandingkan perkembangan usaha (nilai produksi, nilai tambah dan produktivitas input) sebelum dan sesudah menerima bantuan.

\section{Metode Penelitian}

\subsection{Populasi dan Sampel}

Kelompok usaha mikro yang digunakan sebagai obyek penelitian (units of analysis) dalam penelitian ini adalah para pengusaha mikro di wilayah Kabupaten Bogor yang mendapat bantuan P3KUM tahun 2007. Populasi usaha mikro yang memanfaatkan bantuan pada tahun tersebut sebanyak 264 orang dan sampel yang digunakan dalam penelitian ini sebanyak 120 orang. Sampel responden yang dibutuhkan untuk penelitian ini ditentukan dengan cara kombinasi antara cluster sampling dan purposive sampling. Dasar pertimbangan dalam penentuan responden untuk analisis menggunakan kriteria adalah bahwa tidak semua koperasi di Kabupaten Bogor menerima bantuan P3KUM, tidak semua usaha mikro memanfaatkan bantuan pembiayaan P3KUM, dan tidak semua usaha mikro yang mendapat bantuan P3KUM bersedia dijadikan responden.

\subsection{Data dan Teknik Pengumpulan Data}

Data yang digunakan dalam penelitian ini adalah data primer dan data sekunder. Data primer yang dibutuhkan adalah karakteristik usaha mikro yang ditekuni serta kondisi perkembangan usaha mikro, yaitu perkembangan usaha sebelum mendapatkan bantuan dan setelah mendapatkan bantuan. Sedangkan data sekunder dalam penelitian ini adalah berbagai informasi yang dibutuhkan sebagai pendukung analisis, selain yang diperoleh dari responden yang digunakan sebagai sampel.

Pengumpulan data primer dilakukan secara partisipatif melalui diskusi, wawancara dan pengisian kuesioner oleh responden yang sudah ditentukan. Sedangkan data sekunder diperoleh dari studi pustaka, laporan dan dokumen dari berbagai instansi yang terkait dengan bidang penelitian.

Satuan data primer dalam penelitian ini adalah rupiah per periode waktu ( $\mathrm{Rp} / \mathrm{t}$-tertentu). Satuan ini digunakan karena didasarkan pada alasan produk usaha mikro sasaran penelitian ini beragam, baik jenis, model, kualitas, kelas, atau memiliki sifat heterogenitas, sehingga harga jualnya setiap unit produk akan berbeda-beda. Oleh karena itu, jika diambil satuan per satuan (per unit) akan mengalami kesulitan dalam melakukan interpretasi data. Dengan mengambil satuan rupiah per periode waktu (Rp/t-tertentu) tersebut, maka intepretasi keragaman atau homogenitas satuan data 
dapat dilakukan dengan baik, dan tidak bias.

\subsection{Teknik Analisis Data}

Ada tiga tujuan yang ingin dicapai dalam kajian ini, yaitu mengetahui karakteristik usaha mikro yang ada di Kabupaten Bogor, mengetahui peluang usaha mikro dalam mendapatkan bantuan P3KUM dan mengetahui efektivitas pemberdayaan usaha mikro yang sudah dilakukan di Kabupaten Bogor. Berkaitan dengan tujuan tersebut, maka ada tiga teknik analisis yang digunakan dalam penelitian ini adalah sebagai berikut:

\subsubsection{Analisis Deskriptif}

Analisis deskriptif digunakan untuk menganalisis karakteristik usahan mikro yang ada di Kabupaten Bogor yang memanfaatkan bantuan P3KUM tahun 2007. Pendekatan deskriptif digunakan tidak dimaksudkan untuk menguji hipotesis akan tetapi bertujuan untuk menggambarkan realita sosial yang kompleks. Metode analisis deskriptif merupakan prosedur pemecahan masalah yang diselidiki dengan mendiskripsikan kondisi subyek atau obyek penelitian (seseorang, lembaga masyarakat dan lain-lain) pada masa kini berdasarkan faktafakta yang tampak atau sebagaimana mestinya.

\subsubsection{Analisis Chi Kuadrat ( $\left.\mathrm{x}^{2}\right)$ Satu Sampel}

Teknik analisis Chi Kuadrat ( $\mathrm{X}^{2}$ ) satu sampel adalah teknik statistik yang digunakan untuk menguji hipotesis bila dalam populasi terdiri atas dua atau lebih kelas dimana data berbentuk nominal dan sampelnya besar (Sugiyono, 2011:107). Teknik analisis ini digunakan untuk mengetahui peluang dari para pengusaha mikro untuk mendapatkan bantuan pembiayaan produktif dilihat dari lama usaha, jenis produk utama yang dihasilkan, dan jenis usaha, apakah dengan lama usaha, jenis produk utama, dan jenis usaha yang berbeda memberi peluang yang sama atau tidak. Secara matematis rumus dasar Chi Kuadrat ( $\left.x^{2}\right)$ dapat ditulis sebagai berikut:

$$
\chi^{2}=\sum_{\mathrm{i}=1}^{\mathrm{k}} \frac{\left(\mathrm{f}_{\mathrm{o}}-\mathrm{f}_{\mathrm{h}}\right)^{2}}{\mathrm{f}_{\mathrm{h}}}
$$

di mana $\mathrm{x}^{2}$ adalah Chi Kuadrat, fo adalah frekuensi yang diobservasi, fh menunjukkan frekuensi yang diharapkan

Untuk dapat membuat keputusan tentang hipotesis yang diajukan diterima atau ditolak, maka nilai Chi Kuadrat (x2) tersebut dibandingkan dengan Chi Kuadrat (x2) tabel dengan derajat kebebasan (d.k) dan taraf kesalahan tertentu. Derajat kebebasan tidak tergantung pada jumlah individu dalam sampel, namun tergantung pada kebebasan dalam mengisi kolom-kolom pada frekuensi yang diharapan $\left(f_{h}\right)$. Perbandingan tersebut akan ditarik kriteria pengambilan keputusan sebagai berikut:

$\mathrm{H}_{0}$ diterima jika $\mathrm{X}^{2}$ hitung $<\mathrm{X}^{2}$ tabel; a 5\%, d.k. Menyatakan bahwa peluang sampel dalam hal ini pengusaha mikro dengan lama usaha, jenis produk utama, dan jenis usaha yang berbeda untuk mendapatkan bantuan pembiayaan produktif adalah sama atau tidak berbeda.

$\mathrm{H}_{0}$ ditolak jika $\mathrm{X}^{2}$ hitung $>\mathrm{X}^{2}$ tabel; a 5\%, d.k. Menyatakan bahwa peluang sampel dalam hal ini pengusaha mikro lama usaha, jenis produk utama, dan jenis usaha yang berbeda untuk mendapatkan bantuan pembiayaan produktif adalah tidak sama atau berbeda.

\subsubsection{Analisis Uji Peringkat Bertanda Wilcoxon (Wilcoxon Signed Ranks Test)}

Teknik analisis ini digunakan untuk mengetahui efektivitas kebijakan pemberdayaan usaha mikro melalui P3KUM di Kabupaten Bogor. Dipilihnya uji tanda Uji Peringkat Bertanda Wilcoxon sebagai pendekatan analisis ini karena dalam kajian ini bantuan yang diimplementasikan dapat dipandang sebagai treatment. Uji Peringkat Bertanda Wilcoxon adalah salah satu pendekatan analisis yang digunakan untuk mengukur dampak suatu treatment tertentu yang telah atau sedang dilakukan pada suatu kasus. Djarwanto (1989:11) dalam Saragih (2003) mengatakan teknik ini digunakan untuk mengetahui apakah suatu treatment atau tindakan inovasi tertentu (dapat berupa implementasi kebijakan, program, kegiatan, tindakan, perbaikan, teknologi dan sebagainya) yang diberlakukan pada suatu populasi tertentu memiliki dampak yang positif (effect) atau 


\section{Jurnal Ekonomi Pembangunan, 16 (1), Juni 2015, 85-101}

negatif (impact). Pada Uji Peringkat Bertanda Wilcoxon ini efek dari suatu variabel eksperimen atau treatment tidak dapat diukur melainkan hanya dapat diberi tanda positif $(+)$ atau negatif (-) saja. Treatment yang dimaksudkan dalam penelitian ini adalah pemberian bantuan P3KUM kepada usaha mikro di Kabupaten Bogor tahun 2007, terlihat dalam Tabel 1.

Karena jumlah responden yang diteliti lebih banyak dari 30, maka dipergunakan uji $\mathrm{Z}$ dan nilai $\mathrm{Z}$ diasumsikan berdistribusi normal. Dengan demikian metode pendekatan normal dapat dipergunakan.

Pada Uji Peringkat Bertanda Wilcoxon (Wilcoxon Signed Ranks Test) ini data harus dibuat pengurutan (ranking). Untuk menguji hipotesis bahwa $\mu=\mu_{0}$ bagi suatu populasi setangkup yang kontinyu, atau $\mu_{1}=\mu_{2}$ bagi dua populasi setangkup yang kontinyu, pertamatama semua selisih yang sama dengan nol harus dibuang, kemudian memberi peringkat pada $d_{i}$ yang tidak sama dengan nol tanpa memperhatikan tandanya. Peringkat 1 diberikan pada $d_{i}$ dengan nilai absolut terkecil, peringkat 2 pada nilai absolut terkecil berikutnya, dan seterusnya. Bila ada dua atau lebih $d_{i}$ yang nilai mutlaknya sama, maka masingmasing selisih tersebut diberi peringkat rataratanya. Jika hipotesis $\mu=\mu_{0}$ atau $\mu_{1}=\mu_{2}$ benar, maka jumlah total peringkat bagi selisih yang positif $\left(\mathrm{w}_{+}\right)$hampir sama dengan jumlah total peringkat bagi selisih yang negatif (w.). Hipotesis nol $\mu=\mu_{0}$ atau $\mu_{1}=\mu_{2}$ akan ditolak dan alternatifnya $\mu \neq \mu_{0}$ atau $\mu_{1} \neq \mu_{2}$ akan diterima hanya bila $\mathrm{w}_{+}$atau $\mathrm{w}$. yang berarti juga w cukup kecil. Nilai $\mathrm{Z}$ hitung dapat ditentukan dengan rumus sebagai berikut:

$\mathrm{Z}=\frac{\left(\mathrm{W}_{+}-\mu_{\mathrm{W}+}\right)}{\sigma_{\mathrm{W}+}}=\frac{\left(\mathrm{W}_{+}-\frac{\mathrm{n}(\mathrm{n}+1)}{4}\right.}{\sqrt{\frac{\mathrm{n}(\mathrm{n}+1)(2 \mathrm{n}+1)}{24}}}$

Setelah diketahui nilai $\mathrm{Z}$ hitung maka nilai tersebut dibandingkan dengan nilai $\mathrm{Z}$ tabel $(0,05)$ di mana akan dapat diambil kriteria pengambilan keputusan, yaitu:

$\mathrm{H}_{0}$ diterima, jika $\mathrm{H}_{0}=\mu_{1}=\mu_{2}$ dimana $\mathrm{Z}$ hitung $<$ $\mathrm{Z}$ tabel (a 5\%)

Menyatakan bahwa dua buah populasi adalah identik adalah benar. Dapat diharapkan bahwa jumlah total peringkat bagi selisih yang positif $(\mathrm{w}+)$ hampir sama dengan jumlah total peringkat bagi selisih yang negatif (w.). Artinya, bahwa treatment yang dilakukan tidak memiliki pengaruh nyata atau secara signifikan tidak memiliki pengaruh terhadap variabel yang dipengaruhinya.

Tabel 1. Tabulasi Hasil Perhitungan Beda Tanda Positif/Negatif, Dampak Suatu Treatment terhadap Suatu Variabel Penelitian

\begin{tabular}{|c|c|c|c|c|c|c|}
\hline \multirow[t]{2}{*}{ Responden } & \multirow{2}{*}{$\begin{array}{c}\text { Nilai } \\
\text { Sebelum } \\
\text { Bantuan } \\
\left(Y_{i}\right)\end{array}$} & \multirow{2}{*}{$\begin{array}{c}\text { Nilai } \\
\text { Setelah } \\
\text { Bantuan } \\
\left(\mathrm{X}_{\mathrm{i}}\right)\end{array}$} & \multirow{2}{*}{$\begin{array}{c}\text { Nilai } \\
\text { Beda } \\
\text { Tanda } \\
\left(\mathrm{X}_{\mathrm{i}}-\mathrm{Y}_{\mathrm{i}}\right)\end{array}$} & \multicolumn{3}{|c|}{ Tanda Jenjang Peringkat } \\
\hline & & & & Peringkat & $\begin{array}{c}\text { Beda Tanda } \\
\text { Positif } \\
(+)\end{array}$ & $\begin{array}{c}\text { Beda Tanda } \\
\text { Negatif } \\
(-)\end{array}$ \\
\hline$(1)$ & $(2)$ & $(3)$ & $(4)$ & $(5)$ & (6) & (7) \\
\hline 1 & $\mathrm{Y}_{1}$ & $\mathrm{X}_{1}$ & & & & \\
\hline 2 & $\mathrm{Y}_{2}$ & $\mathrm{X}_{2}$ & & & & \\
\hline 3 & $\mathrm{Y}_{3}$ & $\mathrm{X}_{3}$ & & & & \\
\hline 4 & $\mathrm{Y}_{4}$ & $\mathrm{X}_{4}$ & & & & \\
\hline 5 & $\mathrm{Y}_{5}$ & $\mathrm{X}_{5}$ & & & & \\
\hline$:$ & : & : & & & & \\
\hline $\mathrm{n}$ & $Y_{n}$ & $X_{n}$ & & & & \\
\hline
\end{tabular}

Sumber: Sugiyono, 2011

Dimana $\mathrm{Y}_{\mathrm{i}}$ menunjukkan kondisi sebelum treatment, $\mathrm{X}_{\mathrm{i}}$ menunjukkan kondisi setelah treatment, w+ menunjukkan jumlah beda tanda positif, dan w. menunjukkan jumlah beda tanda negatif. 
$\mathrm{H}_{0}$ ditolak jika $\mathrm{H}_{0}=\mu_{1} \neq \mu_{2}$ di mana $\mathrm{Z}$ hitung $>\mathrm{Z}$ tabel (a 5\%)

Menyatakan bahwa dua buah populasi tidak identik, di mana jumlah total peringkat bagi selisih yang positif $\left(\mathrm{w}_{+}\right)$atau jumlah total peringkat bagi selisih yang negatif (w-) yang berarti juga $w$ cukup kecil. Artinya, bahwa treatment yang dilakukan memiliki pengaruh nyata atau secara signifikan memiliki pengaruh terhadap variabel yang dipengaruhinya.

\subsection{Operasional Varibel Tingkat Efektivitas Bantuan P3KUM}

Pendekatan analisis dengan menggunakan Uji Peringkat Bertanda Wilcoxon digunakan untuk mengetahui tingkat efektivitas pemberdayaan usaha mikro melalui P3KUM. Adapun penilaian efektivitas tersebut dilihat dari perkembangan tiga variabel, yaitu peningkatan efektivitas dalam berproduksi, peningkatan perolehan nilai tambah serta peningkatan produktivitas input.

\section{a. Peningkatan efektivitas dalam berproduksi}

Rustam Effendi (1988:22) dalam Saragih (2003) menyatakan tingkat efektivitas suatu produksi adalah membandingkan antara nilai produksi yang dapat terjual dengan nilai potensi yang ada. Dengan demikian tingkat efektivitas merupakan nilai rasio perbandingan antara nilai total penjualan (total sales) dengan nilai total produksi (total product) dalam periode waktu tertentu. Sedangkan Jones (1996:10) dalam Saragih (2003) menyebutkan efektivitas menunjuk pada keberhasilan dan atau kegagalan dalam mencapai suatu tujuan (objective), sehingga efektvitas hanya berkepentingan dengan output.

Berdasar pengertian tersebut, hal penting yang harus diperhatikan adalah bahwa tingkat efektivitas kurang mempertimbangkan berapa banyak pengorbanan (biaya/cost) yang harus diberikan untuk mencapai sasaran, namun hanya membandingkan antara potensi dan realisasi. Oleh karena itu, dalam kaitannya dengan usaha mikro, efektivitas dalam berproduksi dapat dikonsepsikan sebagai rasio atau tingkat perbandingan nilai total penjualan (total sales) dan nilai total produksi per periode waktu tertentu dari kegiatan usaha usaha mikro dan pada umumnya dapat dinyatakan dalam persentase. Secara matematis tingkat efektivitas dalam berproduksi pada usaha mikro dapat dituliskan sebagai berikut:

$\mathrm{Eft}=\frac{\mathrm{TS}}{\mathrm{TP}} \times 100 \%$

di mana Eft adalah tingkat efektivitas dalam berproduksi per periode waktu tertentu (\%), TP menunjukkan nilai total produksi/Total Production per periode waktu tertentu (rp/bln), TS menunjukkan nilai penjualan/Total Sales per periode waktu tertentu (rp/bln).

\section{b. Peningkatan perolehan nilai tambah}

Nilai tambah atau value added sering diartikan sebagai tambahan manfaat ekonomi dari adanya perbaikan teknologi, manajemen, kualitas \& diversifikasi produksi. Menurut Damanhuri (1996:87), nilai tambah dapat didefiniskan sebagai tambahan nilai yang terkandung pada jasa yang diciptakan oleh sebuah organisasi/ perusahaan. Menurut Yovani (2001:22), pada dasarnya dalam rangka menghitung nilai tambah (value added) suatu usaha dapat ditentukan dengan dua cara yaitu dengan (a) metode pengurangan (substraction method) dan (b) metode penambahn (additional method).

Metode pengurangan tidak memasukkan biaya-biaya yang biasanya sulit diperoleh dari usaha mikro seperti depresiasi, pajak, dan lainlain. Dengan kata lain hanya memasukkan unsur-unsur biaya seperti pembelian material, pembelian energi (BBM), perawatan (biaya perawatan pembelian suku cadang), ATK dan administrasi serta pungutan lain (retribusi, keamanan, kebersihan) dan pembelian lainlain. Dalam istilah ekonomi biaya ini disebut dengan value of purchase from outside. Sedangkan metode penambahan memasukkan biaya seperti depresiasi, pajak, dan lain-lain. Dengan kata lain selain memasukkan value of purchase from outside juga ditambah dengan depresiasi, pajak, dan lain-lain.

Oleh karena obyek yang akan diteliti adalah usaha mikro di mana pada umumnya tidak memiliki data pembukuan yang lengkap, maka metode yang digunakan untuk menghitung Value Added ini adalah metode pengurangan. 


\section{Jurnal Ekonomi Pembangunan, 16 (1), Juni 2015, 85-101}

Menurut Yovani (2001:22), metode perhitungan Value Added ini secara matematis dirumuskan sebagai berikut:

$\mathrm{VA}=\mathrm{TS}-\mathrm{VPO}$

di mana VA menunjukkan nilai tambah per periode waktu tertentu (rp/bln), TS menunjukkan total penjualan atau Net Sales per periode waktu tertentu (rp/bln), VPO menunjukkan Value of Purchase from Outside per periode waktu tertentu (rp/bln). Sedangkan nilai VPO per periode waktu tertentu (rp/bln) dalam penelitian ini ditentukan sebagai berikut:

$\mathrm{VPO}=\mathrm{MP}+\mathrm{EP}+\mathrm{MC}+\mathrm{AP}+\mathrm{RC}+\mathrm{AC}$

di mana MP menunjukkan pembelian material (material purchased) per periode waktu tertentu (rp/bln), EP menunjukkan pembelian energy (energy purchased) dalam hal ini adalah BBM per periode waktu tertentu (rp/bln), MC menunjukkan perawatan mesin (pembelian suku cadang dan biaya perawatan) per periode waktu tertentu (rp/bln), AP menunjukkan biaya pembelian ATK dan administrasi per periode waktu tertentu (rp/bln), RC menunjukkan biaya pembayaran pungutan lain, dan AC menunjukkan biaya lain-lain.

\section{c. Peningkatan produktivitas input}

Produktivitas secara umum didefinisikan perbandingan antara output dengan input. Dengan kata lain produktivitas adalah sebuah ukuran untuk melihat seberapa baik input atau sumber daya yang digunakan untuk menciptakan output yang diinginkan. Semakin tinggi nilai rasio maka semakin tinggi produktivitasnya. Dengan demikian produktivitas akan meningkat apabila dengan input yang sama dapat diperoleh hasil yang lebih tinggi, atau sebaliknya dengan tingkat hasil yang tinggi hanya membutuhkan input yang lebih rendah. Produktivitas juga dapat diartikan sebagai suatu ukuran yang menyatakan bagaimana baiknya sumber daya diatur dan dimanfaatkan untuk mencapai hasil yang maksimal. Menurut Kurnia dan Hermawa (2014:3) produktivitas dapat digunakan sebagai tolak ukur keberhasilan suatu industri atau UKM dalam menghasilkan barang atau jasa sehingga semakin tinggi perbandingannya berarti semakin tinggi barang yang dihasilkan.

Yovani (2001:20) menyebutkan, dalam mengukur produktivitas, langkah yang harus dilakukan adalah mengukur tingkat output. Ada dua jenis ukuran yang digunakan dalam mengukur tingkat output ini, yaitu (a) berdasarkan volume produk fisik yang dihasilkan (product quantity), (b) berdasarkan nilai uang yang menunjukkan nilai tambah (Value Added) yang sebenarnya dari suatu perusahaan.

Mengingat produk usaha mikro dalam penelitian ini adalah heterogen, maka pengukuran tingkat output dengan cara Value Added adalah pendekatan yang paling tepat. Di mana Value Added mengukur tingkat output yang diekspresikan dalam satuan jumlah uang. Dengan heteroginitas semacam itu, tentunya tingkat output akan lebih mudah dihitung bila menggunakan satuan yang sama, yaitu uang (dalam rupiah). Sementara dalam menghitung nilai input, akan digunakan dua jenis input, yaitu tenaga kerja dan modal.

Mengingat heteroginitas produk dari usaha mikro yang ada, maka perhitungan nilai input tenaga kerja yang digunakan akan digunakan metode perhitungan biaya per individu (personal expenses), mengingat perhitungan output menggunakan satuan uang (dalam rupiah). Perhitungan ini diturunkan dengan cara menjumlahkan semua pengeluaran yang diterima pekerja atau pegawai seperti gaji atau upah, bonus, jaminan sosial, dan lain-lain, dengan rumus sebagai berikut:

$\mathrm{LC}=\mathrm{Cgi}+\mathrm{Chn}+\mathrm{Ctp}+\mathrm{Cbn}$

di mana LC menunjukkan Labor Cost atau biaya untuk tenaga kerja per periode waktu tertentu (rp/bln), Cgi menunjukkan total biaya atas gaji pekerja per periode waktu tertentu (rp/bln), Chn menunjukkan total biaya honor pekerja tidak tetap per periode waktu tertentu (rp/bln), Ctp menunjukkan total biaya tunjangan pekerja per periode waktu tertentu (rp/bln), 
Cbn menunjukkan total biaya bonus pekerja per periode waktu tertentu (rp/bln).

Demikian pula mengingat heteroginitas produk dari usaha mikro yang ada, maka perhitungan nilai modal yang digunakan didasarkan pada data total aset yang dimiliki usaha mikro baik asset bergerak maupun asset tidak bergerak. Rumus yang digunakan untuk menghitung nilai input modal adalah sebagai berikut:

$\mathrm{TC}=\mathrm{TC}$ bergerak $+\mathrm{TC}$ tidak bergerak

di mana TC menunjukkan Total Capital atau Modal, TC bergerak menunjukkan total aset bergerak, TC tidak bergerak menunjukkan total aset tidak bergerak.

Seperti halnya konsep perhitungan sebelumnya, maka perhitungan tingkat produktivitas usaha adalah dengan cara mengitung tingkat produktivitas tenaga kerja dan tingkat produktivitas modal, dimana secara matematis dapat dirumuskan sebagai berikut:

$$
\mathrm{LP}=\frac{\mathrm{NT}}{\mathrm{LC}}
$$

di mana LP menunjukkan Labor Productivity per periode waktu tertentu, NT menunjukkan Value Added per periode waktu tertentu (rp/ bln), LC menunjukkan Labor Cost atau biaya untuk tenaga kerja per periode waktu tertentu (rp/bln).

$$
\mathrm{CP}=\frac{\mathrm{NT}}{\mathrm{CC}}
$$

di mana CP menunjukkan Capital Productivity per periode waktu tertentu, NT menunjukkan Value Added per periode waktu tertentu (rp/ bln), CC menunjukkan Total Capital (rp/bln).

\section{Hasil dan Pembahasan}

Proses pengajuan pinjaman bantuan P3KUM di Kabupaten Bogor-Jawa Barat tahun 2007 berjalan lancar. Namun demikian, temuan di lapangan menunjukkan, sistem monitoring dan evaluasi dari Dinas Koperasi dan Perindag Kabupaten Bogor belum berjalan secara optimal, sehingga ditemukan adanya koperasi yang melakukan penyimpangan baik dalam hal pemanfaatan bantuan maupun yang alamatnya tidak ditemukan.

Proses pengajuan bantuan diawali dari sosialisasi dari pihak Kementerian Negara Koperasi dan UKM kepada SKPD terkait di tingkat kabupaten untuk selanjutnya disosialisasikan ke semua koperasi di wilayahnya dan yang berminat diminta membuat proposal. Proposal dikumpulkan untuk diverifikasi lebih lanjut ke tingkat kabupaten, untuk selanjutnya diserahkan ke tingkat provinsi dan akhirnya dikirim ke pusat. Di tingkat pusat, pihak Kementerian Negara Koperasi dan UKM mengeluarkan keputusan mengenai koperasi yang berhak menerima dana bantuan P3KUM. Pemberian dana langsung diberikan ke rekening koperasi bersangkutan, tidak melalui pemerintah daerah provinsi atau kabupaten. Dalam proses pencairan dana, koperasi penerima bantuan yang menjadi responden menemukan beberapa kendala. Kendala pertama adalah adanya proses yang berbelit-belit di pencairan dananya. Kendala lain adalah biaya yang cukup besar yang harus ditanggung koperasi ketika proses pengiriman data ke pihak provinsi dan pusat, baik biaya transportasi maupun akomodasi, yang besarannya sampai sekitar $10 \%$ dari besarnya bantuan yang diberikan.

Dalam perjalanannya, tidak semua koperasi yang mendapatkan bantuan P3KUM berjalan seperti yang diharapkan. Di antara 7 koperasi yang mendapatkan bantuan P3KUM di Kabupaten Bogor tahun 2007, hanya 4 koperasi berjalan baik, dalam arti tingkat pengembalian dana bantuan cukup lancar, sedangkan 3 koperasi lainnya ada yang tutup ada pula yang bermasalah dalam pengembalian dana bantuan. Kelancaran pengembalian dana bantuan ini paling tidak tergantung pada 2 hal. Pertama, kondisi kesehatan atau kinerja koperasi penerima bantuan. Temuan di lapangan menunjukkan ada beberapa koperasi penerima bantuan yang memiliki manajemen dan kinerja keuangan yang kurang baik, dan tidak didukung dengan pendampingan dan monitoring dari pemerintah pusat dan daerah yang kontinyu sehingga menyebabkan koperasi-koperasi tersebut dalam perjalanannya menjadi bermasalah bahkan tutup. Sederhananya proses perijinan pendirian koperasi, juga menjadi faktor penyebab. Ada beberapa koperasi yang didirikan 


\section{Jurnal Ekonomi Pembangunan, 16 (1), Juni 2015, 85-101}

tidak didasari dari keinginan anggota untuk mendirikannya, tapi muncul dari keinginan sekelompok orang yang hanya ingin mendapatkan dana bantuan dalam jumlah besar dengan jasa kecil untuk kepentingan pribadi.

Penyebab kedua adalah dari pengusaha mikro yang memanfaatkan bantuan. Persepsi sebagian pengusaha mikro terhadap dana bantuan P3KUM dari pemerintah sebagai dana hibah sehingga tidak perlu dikembalikan kepada pemerintah, menjadikan tingkat pengembalian pinjaman anggota atau nasabah dari beberapa koperasi tidak terlalu bagus. Selain itu proses pengajuan pinjaman modal juga sangat sederhana, hanya berdasarkan rekomendasi anggota atau nasabah lain, jaminan KTP, atau buku tabungan bahkan ada yang hanya berdasar pada kepercayaan, dan kurang didukung dengan upaya pendampingan dan monitoring dari pihak koperasi menyebabkan tidak sedikit usaha mikro yang memanfaatkan dana bantuan tersebut tidak berkembang, tutup atau dana bantuan tersebut justru digunakan untuk tujuan konsumtif. Kebijakan perijinan untuk minimarket/supermarket juga memberi kontribusi negatif pada pedagang-pedagang di pasar tradisional, yang sebagian besar adalah pengusaha mikro. Berdirinya usaha-usaha tersebut berpengaruh pada omzet dan keuntungan, yang selanjutnya berakibat pada tingkat kelancaran pelunasan/ pembayaran cicilan ke koperasi.

Di Kabupaten Bogor, dana bergulir P3KUM tahun 2007 disalurkan melalui 7 koperasi baik yang bergerak secara konvensional maupun syariah dimana masing-masing koperasi mendapatkan Rp100.000.000 (seratus juta rupiah). Setiap pengusaha mikro anggota koperasi dapat memanfaatkan dana bergulir tersebut dalam bentuk pinjaman maksimal Rp4.000.000 (empat juta rupiah). Disalurkannya dana bergulir melalui koperasi memiliki dua tujuan, yang pertama adalah membantu peningkatan perkembangan usaha dari usaha mikro yang biasanya belum bankable, dan yang kedua adalah meningkatkan perkembangan usaha koperasi tempat pengusaha mikro mendapatkan dana tersebut. Dengan demikian diharapkan tingkat kemiskinan masyarakat berkurang dan sekaligus kemauan masyarakat untuk menjadi anggota koperasi juga meningkat.

\subsection{Karakteristik Responden}

Di antara 120 responden, 72,5 persen berjenis kelamin laki-laki, dan 27,5 persen berjenis kelamin perempuan. Kondisi ini dapat menggambarkan bahwa sampai tahun 2010, usaha mikro di wilayah kabupaten Bogor yang memanfaatkan bantuan masih didominasi laki-laki. Jika dilihat perkelompok usia, usia responden bervariasi dari paling muda 22 tahun sampai paling tua 79 tahun. Sebagian besar ada pada kelompok usia produktif (30-53 tahun), yaitu sebanyak 83 persen.

Tingkat pendidikan responden tersebar dari yang tidak sekolah sampai yang berpendidikan perguruan tinggi. Sebagian besar berpendidikan SLTA (55 persen), dan 1,7 persen yang tidak sekolah dan berpendidikan perguruan tinggi. Dua responden yang berpendidikan tinggi ada pada kelompok usia muda (22-37 tahun), sedangkan dua orang yang tidak sekolah adalah responden pada usia di atas 70 tahun. 97,5 persen responden sudah menikah dan sisanya 2,5 persen tidak menikah. Sedangkan 100 persen dari responden merupakan anggota koperasi.

Karakteristik usaha responden dilihat dari lama usaha, jenis produk utama, jenis usaha, bentuk usaha dan pasar. Jika dilihat dari lama usahanya, semua responden sudah menjalankan usahanya lebih dari 1 tahun, 40,8 persen usahanya sudah berjalan lebih dari 10 tahun, 29,2 persen lama usahanya 5-10 tahun, 30 persen lama usahanya 1-5 tahun. 44,2 persen responden menghasilkan kelompok produk makanan, minuman dan sejenisnya, 18,3 persen menghasilkan jenis produk tekstil dan sejenisnya, 4,2 persen menghasilkan jenis produk bukan logam, 10,8 persen menghasilkan produk kayu dan sejenisnya dan 22,5 persen menghasilkan produk jasa. Sebagian besar responden bergerak di bidang perdagangan (60 persen) dan tidak ada satupun yang dari pertanian. Sektor pengolahan cukup banyak, sekitar 26,7 persen dan sektor jasa sebesar $13,3 \%$. 
Jika dilihat dari bentuk usahanya dan pasar produknya, sebagian besar $(98,3 \%)$ merupakan perusahaan perseorangan, dan sisanya $(1,7 \%)$ merupakan memiliki bentuk badan usaha CV yang bergerak di bidang furniture. Sebagian besar responden menjual produknya di wilayah Kabupaten Bogor (59,2 persen), sebanyak 36,7 persen menjual produknya baik di dalam maupun di luar wilayah Kabupaten Bogor dan hanya 4 persen yang menjual produknya di luar Kabupaten Bogor.

\subsection{Peluang Usaha Mikro untuk Mendapatkan Bantuan}

Analisis ini melihat peluang pengusaha mikro untuk mendapatkan bantuan dana bergulir dengan menggunakan tiga indikator yaitu lamanya usaha yang sudah dijalankan, jenis produk utama yang dihasilkan, dan jenis usaha yang dijalankan. Hipotesis nol yang dibangun adalah bahwa peluang pengusaha mikro untuk mendapatkan bantuan jika dilihat dari tiga indikator tersebut adalah sama. Hasil Uji Statistik dapat dilihat pada tabel berikut:

Tabel 2 menjelaskan bahwa jika dilihat dari variabel lama usaha, diketahui nilai (x2) hitung sebesar 3,050. Dengan derajat kebebasan sebesar 1 dan tingkat kesalahan 5\% maka diketahui nilai $\left(x^{2}\right)$ tabel sebesar 3,841. Karena nilai $\left(x^{2}\right)$ hitung lebih kecil dari nilai $\left(x^{2}\right)$ tabel $(3,050<3,841)$ maka $\mathrm{H}_{0}$ diterima dan $\mathrm{H}_{\mathrm{a}}$ ditolak. Ini berarti peluang usaha mikro untuk mendapatkan bantuan P3KUM jika dilihat dari lama usaha adalah sama. Berdasarkan data sampel ternyata lamanya usaha dari usaha mikro yang mendapatkan bantuan tidak berbeda terlalu jauh.

Jika dilihat dari variabel jenis produk utama yang dihasilkan, diketahui nilai (x2) hitung sebesar 55,667. Dengan derajat kebebasan sebesar 1 dan tingkat kesalahan 5\% maka diketahui nilai (x2) tabel sebesar 3,841. Karena nilai ( $\left.x^{2}\right)$ hitung lebih besar dari nilai $\left(\mathrm{x}^{2}\right)$ tabel (55,667 >
3,841), maka $\mathrm{H}_{0}$ ditolak dan $\mathrm{H}_{\mathrm{a}}$ diterima. Ini berarti peluang usaha mikro untuk mendapatkan bantuan P3KUM jika dilihat dari jenis produk utama yang dihasilkan adalah berbeda atau tidak sama. Berdasarkan data sampel ternyata usaha mikro yang menghasilkan produk makanan dan sejenisnya mendapat peluang paling tinggi untuk mendapatkan bantuan P3KUM.

Jika dilihat dari variabel jenis usaha yang dijalankan, diketahui nilai ( $\mathrm{x}^{2}$ ) hitung sebesar 86,133. Dengan derajat kebebasan sebesar 1 dan tingkat kesalahan 5\% maka diketahui nilai (x2) tabel sebesar 3,841. Karena nilai (x2) hitung lebih besar dari nilai $\left(\mathrm{x}^{2}\right)$ tabel $(86,133>3,841)$. maka $\mathrm{H}_{0}$ ditolak dan $\mathrm{H}_{\mathrm{a}}$ diterima. Ini berarti peluang usaha mikro untuk mendapatkan bantuan P3KUM jika dilihat dari jenis usaha yang dijalankan adalah berbeda atau tidak sama. Berdasarkan data sampel ternyata usaha mikro di sektor perdagangan mendapat peluang paling tinggi untuk mendapatkan bantuan P3KUM.

Berdasarkan hasil pengujian statistik tersebut, secara keseluruhan dapat diuraikan bahwa peluang usaha mikro untuk memanfaatkan bantuan P3KUM bervariasi. Jika dilihat dari sisi lamanya usaha yang sudah dijalankan, peluang usaha mikro untuk mendapatkan bantuan adalah sama, sepanjang persyaratanpersyaratan administrasi terpenuhi. Koperasi sebagai penyalur bantuan P3KUM lebih mempertimbangkan kelayakan usaha dan indikator lain seperti rekomendasi dan persyaratan administrasi dibandingkan lama usaha yang sudah dijalankan. Namun jika dilihat dari jenis produk yang dihasilkan dan jenis usaha yang dijalankan, peluang usaha mikro untuk mendapatkan bantuan P3KUM berbeda atau tidak sama.

Usaha mikro yang menghasilkan produk makanan dan bergerak di sektor perdagangan memiliki peluang yang lebih besar dibanding

Tabel 2. Hasil Uji Statistik Peluang

\begin{tabular}{rlcccl}
\hline No. & \multicolumn{1}{c}{ Variabel } & $(\chi 2)$ hitung & $(\chi 2)$ tabel & Signifikansi & Kesimpulan \\
\hline 1. & Lama Usaha & 3,050 & 3,841 & 0,218 & Terima $\mathrm{H}_{0}$ \\
2. & Jenis Produk & 55,667 & 3,841 & 0,000 & Tolak $\mathrm{H}_{0}$ \\
3. & Jenis Usaha & 86,133 & 3,841 & 0,000 & Tolak $\mathrm{H}_{0}$ \\
\hline
\end{tabular}

Sumber: Output SPSS 


\section{Jurnal Ekonomi Pembangunan, 16 (1), Juni 2015, 85-101}

usaha mikro yang menghasilkan produk lainnya dan bergerak di sektor selain perdagangan. Kondisi ini dapat dilihat dari dua sisi. Pertama, hasil penelitian menunjukkan sebagian besar pengusaha kecil mendapatkan informasi adanya bantuan pinjaman adalah dari teman sesama pengusaha sejenis yang sudah terlebih dahulu mendapatkan bantuan pinjaman yang sekaligus merekomendasikannya. Mereka sebagian besar adalah para pedagang makanan di pasar. Sistem rekomendasi ini menyebabkan untuk kasus di Kabupaten Bogor sebagian besar yang memanfaatkan dana bantuan adalah pedagang makanan. Kedua, dalam penyaluran dana bantuan, koperasi juga mempertimbangkan lokasi. Dalam rangka kemudahan dalam monitoring, ada koperasi yang mengkonsentrasikan pemberian bantuan pada pengusaha mikro di sentra-sentra tertentu yang mudah dalam jangkauan pengawasan koperasi. Berdasarkan data yang ada, pasar merupakan lokasi di mana pengusaha mikro mendapatkan bantuan.

\subsection{Efektivitas Pemberdayaan Usaha Mikro}

Analisis ini pada dasarnya mengkaji pengaruh implementasi P3KUM pada usaha mikro terhadap perubahan tingkat nilai variabel perkembangan usaha berdampak nyata atau signifikan, atau dengan kata lain analisis ini melihat efektivitas bantuan P3KUM yang diberikan oleh pemerintah. Tingkat efektivitas dilihat dari empat indikator yaitu peningkatan efekti- vitas dalam berproduksi, peningkatan perolehan nilai tambah, peningkatan produktivitas input modal dan ten aga kerja, dengan membandingkan antara kondisi sebelum mendapat bantuan dan kondisi sesudah mendapat bantuan. Efektivitas dilihat dengan membandingkan antara nilai mutlak $\mathrm{Z}$ hitung dengan nilai $\mathrm{Z}$ tabel pada tingkat kesalahan 5\%. Hipotesis nol yang dibangun adalah bahwa tidak ada perbedaan efektivitas produksi, nilai tambah, produktivitas tenaga kerja dan produktivitas modal antara kondisi sebelum mendapat bantuan dan kondisi sesudah mendapat bantuan dana bergulir. Hasil uji statistik dapat dilihat pada tabel 3 .

Tabel 3 menjelaskan bahwa jika dilihat dari tingkat efektivitas dalam berproduksi, dengan taraf kesalahan (x2) 0,025 (0,05/2) maka nilai Z tabel adalah $\pm 1,96$. Dengan nilai $\mathrm{Z}$ hitung sebesar 6,043 (nilai mutlak) maka pada tingkat kesalahan 0,025, nilai $\mathrm{Z}$ hitung lebih besar dibandingkan dengan nilai $\mathrm{Z}$ tabel ( 6,043 > 1,96), dengan demikian hipotesis nol ditolak. Sehingga dapat disimpulkan pemberian bantuan dana bergulir P3KUM berpengaruh secara signifikan dalam meningkatkan efektivitas dalam berproduksi usaha mikro di Kabupaten Bogor.

Jika dilihat dari tingkat perolehan nilai tambah, dengan taraf kesalahan (x2) 0,025 $(0,05 / 2)$ maka nilai $\mathrm{Z}$ tabel adalah $\pm 1,96$. Dengan nilai $\mathrm{Z}$ hitung sebesar 9,336 (nilai mutlak) mak a pada tingkat kesalahan 0,025 , nilai $\mathrm{Z}$ hitung lebih besar dibandingkan dengan

Tabel 3. Hasil Analisis Efektivitas Bantuan P3KUM terhadap Perkembangan Usaha Mikro di Kabupaten Bogor

\begin{tabular}{llccccc}
\hline No & $\begin{array}{c}\text { Variabel perkembangan } \\
\text { usaha mikro }\end{array}$ & $\begin{array}{c}\text { Jumlah beda } \\
\text { tanda }(+)\end{array}$ & $\begin{array}{c}\text { Juml beda } \\
\text { tanda }(-)\end{array}$ & $\begin{array}{c}\text { Nilai Z } \\
\text { hitung }\end{array}$ & $\begin{array}{c}\text { Nilai Z } \\
\text { tabel }\end{array}$ & Keputusan \\
\hline 1. & $\begin{array}{l}\text { Tingkat efektivitas } \\
\text { dalam berproduksi }\end{array}$ & 85 & 21 & $-6,043$ & $\pm 1,96$ & signifikan \\
& $\begin{array}{l}\left.\mathrm{n}_{1}\right) \\
\text { Tingkat perolehan nilai }\end{array}$ & 113 & 6 & $-9,336$ & $\pm 1,96$ & signifikan \\
tambah & $\begin{array}{l}\text { Tingkat produktivitas } \\
\text { tenaga kerja }\end{array}$ & 53 & 66 & $-0,822$ & $\pm 1,96$ & tidak signifikan \\
Tingkat produktivitas & 93 & 22 & $-6,341$ & $\pm 1,96$ & signifikan \\
\hline
\end{tabular}

Sumber: Output SPSS 
nilai $\mathrm{Z}$ tabel $(9,336>1,96)$, dengan demikian hipotesis nol ditolak. Sehingga dapat disimpulkan pemberian bantuan dana bergulir P3KUM berpengaruh secara signifikan dalam meningkatkan perolehan nilai tambah usaha mikro di Kabupaten Bogor.

Jika dilihat dari tingkat dari produktivitas tenaga kerja, dengan taraf kesalahan (a) 0,025 $(0,05 / 2)$ maka nilai $\mathrm{Z}$ tabel adalah $\pm 1,96$. Dengan nilai $\mathrm{Z}$ hitung sebesar 0,822 (nilai mutlak) maka pada tingkat kesalahan 0,025, nilai $\mathrm{Z}$ hitung lebih besar dibandingkan dengan nilai $\mathrm{Z}$ tabel $(0,822<1,96)$, dengan demikian hipotesis nol diterima. Sehingga dapat disimpulkan pemberian bantuan dana bergulir P3KUM secara signifikan tidak berpengaruh dalam meningkatkan produktivitas tenaga kerja usaha mikro di Kabupaten Bogor.

Jika dilihat dari tingkat dari produktivitas modal, dengan taraf kesalahan (a) 0,025 (0,05/ 2) (nilai mutlak) maka nilai $Z$ tabel adalah \pm 1,96. Dengan nilai $Z$ hitung sebesar 6,341 maka pada tingkat kesalahan 0,025 , nilai $\mathrm{Z}$ hitung lebih besar dibandingkan dengan nilai $\mathrm{Z}$ tabel $(6,341>1,96)$, dengan demikian hipotesis nol ditolak. Sehingga dapat disimpulkan pemberian bantuan dana bergulir P3KUM berpengaruh secara signifikan dalam meningkatkan produktivitas modal usaha mikro di Kabupaten Bogor.

Pemberian bantuan dana bergulir bagi pengusaha mikro di Kabupaten tahun 2007 juga secara signifikan mampu meningkatkan perkembangan usaha dari usaha kecil yang ada di Kabupaten Bogor, kecuali peningkatan produktivitas tenaga kerja. Pinjaman bergulir P3KUM rata-rata $\mathrm{Rp} 4.000 .000$ (empat juta rupiah) ternyata efektif dalam meningkatkan produksi, nilai tambah, dan produktivitas modal. Ini sejalan dengan hasil penelitian Qodri (2006) yang menyatakan bahwa bantuan modal usaha baik yang bersumber dari dana bergulir maupun bersumber dari luar dana bergulir berperan nyata dalam mengembangkan usaha tersebut yang diindikasikan dari perolehan laba. Yulinar (2007) yang meneliti faktor-faktor yang mendorong pertumbuhan UKM di provinsi Lampung, juga menyatakan bahwa variabel Investasi adalah yang paling berpengaruh terhadap pertumbuhan UKM di Provinsi Lampung. Sedangkan tidak adanya peningkatan produktivitas tenaga kerja ini mengindikasikan bahwa bantuan dana bergulir P3KUM yang dimanfaatkan para pengusaha mikro masih sebatas memberi dampak positif dari sisi produksi dan modal, sehingga permasalahan produktivitas tenaga kerja tidak bisa diatasi dengan penambahan modal namun dengan treatment-treatment lain seperti pelatihan, pendampingan dan sebagainya. Jika dilihat dari sebaran perkembangan usaha, nilai perkembangan usaha dari usaha mikro yang menjadi responden sebagian besar mengalami peningkatan, walaupun nilai peningkatan tidak terlalu besar. Peningkatan perkembangan usaha dari usaha mikro lebih pada keberlanjutan usaha tersebut namun belum sampai meningkatkan posisi dari usaha mikro menjadi usaha kecil atau menengah.

Dengan treatment bantuan dana bergulir P3KUM, usaha mikro yang mengalami peningkatan produksi sekitar 71 persen, yang tidak mengalami peningkatan sekitar 12 persen dan yang mengalami penurunan sekitar 17 persen. Sebagian besar perkuatan permodalan melalui P3KUM yang diterima, secara langsung mempengaruhi volume usaha (omset). Jika treatment tersebut digunakan untuk investasi atau untuk melakukan diversifikasi usaha, maka akan meningkatkan kesempatan kerja, yang pada akhirnya akan menambah volume usaha juga. Sedangkan adanya penurunan produksi tersebut dapat dikatakan ada faktor lain yang menyebabkan terjadinya penurunan walaupun sudah ada penguatan permodalan. Sebagian besar usaha mikro menghasilkan produk makanan dan bergerak di bidang perdagangan. Bisnis penjualan makanan sangat sensitif terhadap perubahan harga (inflasi) karena akan menyebabkan daya beli konsumen menurun. Di samping itu, produk makanan jenisnya relatif homogen, sehingga persaingan antarpengusaha sangat kuat.

Treatment dana bergulir P3KUM juga mampu meningkatkan nilai tambah produksi. Usaha mikro yang mengalami peningkatan nilai tambah sekitar 94 persen, yang tidak mengalami peningkatan ada 1 persen dan yang mengalami penurunan sekitar 5 persen. Tingginya persentase usaha mikro yang mengalami peningkatan nilai tambah sebagai dampak dari pemanfaatan dana bergulir merupakan kondisi 


\section{Jurnal Ekonomi Pembangunan, 16 (1), Juni 2015, 85-101}

adanya perbaikan manajemen, teknologi atau diversifikasi produk usaha mikro setelah memanfaatkan bantuan tersebut. Namun demikian walaupun dalam persentase yang kecil, masih adanya sekitar usaha mikro yang meng. alami penurunan nilai tambah setelah mendapatkan bantuan dana bergulir mengindikasikan masih adanya permasalahan yang dihadapi pengusaha di samping permasalahan modal.

Jika dilihat dari peningkatan produktivitas modal sebagai dampak dari treatment dana bergulir, usaha mikro yang mengalami peningkatan produktivitas modal sekitar 77,5 persen, yang tidak mengalami peningkatan ada 4,2 persen dan yang mengalami penurunan sekitar 18,3 persen. Kondisi sejalan dengan upaya pemerintah untuk mengatasi permasalahan permodalan yang dihadapi usaha mikro. Program bantuan dana bergulir P3KUM yang diharapkan membantu permasalahan permodalan ternyata efektif meningkatkan produktivitas modal usaha mikro yang memanfaatkan bantuan. Penguatan permodalan tersebut membuat pengusaha mikro lebih leluasa untuk memanfaatkan modal tersebut dalam dalam meningkatkan volume usahanya. Sedangkan adanya beberapa pengusaha mikro yang justru mengalami penurunan produktivitas modalnya, temuan di lapangan menunjukkan adanya ketidaktepatan sasaran dalam penggunaan bantuan tersebut. Ditemukan sebagian pengusaha mikro justru memanfaatkan dana bantuan tersebut untuk tujuan-tujuan konsumtif dan tidak berdampak pada peningkatan usahanya.

\section{Simpulan}

Kajian ini khusus menganalisis efektivitas pemberdayaan usaha mikro di Kabupaten Bogor, dengan bantuan P3KUM yang disalurkan kepada usaha mikro di wilayah Kabupaten Bogor pada tahun 2007. Analisis berkaitan dengan karakteristik usaha mikro yang ada di Kabupaten Bogor, peluang usaha mikro untuk mendapatkan bantuan dilihat dari perbedaan lama usaha, jenis produk utama yang dihasilkan, jenis usaha; serta melihat efektivitas bantuan yang diberikan terhadap peningkatan perkembangan usaha.

Karakteristik responden sangat bervariasi. Jika dilihat dari lama usaha, responden telah menjalankan usahanya antara satu sampai sepuluh tahun. Responden memiliki jenis produk utama yang bervariasi baik makanan, tekstil, produk kayu, dan lain-lain, dan jika dilihat dari jenis usaha paling banyak adalah usaha mikro yang bergerak di bidang perdagangan. Sebagian besar responden merupakan usaha perseorangan yang menjual produknya di wilayah Kabupaten Bogor.

Dalam mendapatkan bantuan, peluang setiap usaha mikro di wilayah Kabupaten Bogor bervariasi. Jika dilihat dari lamanya usaha, peluang usaha kecil untuk mendapatkan bantuan adalah sama, sedangkan jika dilihat dari indikator jenis produk utama yang dihasilkan, dan jenis usaha, peluangnya tidak sama. Peluang usaha mikro yang menghasilkan produk makanan dan bergerak di sektor perdagangan lebih besar dibanding lainnya.

Program bantuan P3KUM yang diberikan pemerintah pada tahun 2007 efektif dalam menaikkan perkembangan usaha dari usaha mikro. Bantuan tersebut secara signifikan mampu menaikkan nilai produksi, nilai tambah dan produktivitas modal, namun secara signifikan tidak mampu menaikkan produktivitas tenaga kerja.

Keberhasilan program pemberdayaan usaha mikro di Kabupaten Bogor tidak dapat dilepaskan dari berbagai pihak, baik stakeholder maupun pengusaha mikro sendiri. Berdasarkan hasil penelitian dapat disarankan bahwa bantuan untuk pemberdayaan usaha mikro seyogyanya dilakukan secara komprehensif, dengan memetakan permasalahan yang sebenarnya dihadapi oleh para pengusaha mikro. Upaya bantuan penguatan permodalan harus bersama-sama dengan upaya-upaya lain yang sifatnya komplemen seperti penyuluhan, pelatihan, pendampingan, workshop, pendirian sentra-sentra usaha mikro sehingga bantuanbantuan yang diberikan benar-benar mampu meningkatkan kinerja usaha mikro.

Dalam penyaluran bantuan, seyogyanya diikuti dengan monitoring yang kontinyu, 
untuk mengawal sampai sejauh mana modal yang disalurkan digunakan, kendala-kendala yang dihadapi usaha mikro dan pemanfaatan pinjaman modal tersebut apakah sudah tepat sasaran atau tidak. Demikian pula, monitoring yang kontinyu juga seyogyanya dilakukan oleh pemerintah daerah kepada koperasi yang mendapatkan bantuan, agar bantuan dapat disalurkan sebagaimana mestinya sesuai dengan aturan-aturan yang diberlakukan.

Dalam upaya pemberdayaan usaha mikro, perlu adanya kebijakan-kebijakan yang sifatnya sinergis antarlembaga pemerintah,. Kebijakan perijinan minimarket/supermarket perlu ditinjau kembali agar tidak menekan keberadaan dan kelangsungan usaha dari pelaku usaha mikro.

\section{Daftar Pustaka}

Damanhuri, D.S., 1996. Ekonomi politik alternatif: agenda reformasi abad 21. Jakarta: Pustaka Sinar Harapan.

Ghozali, Imam. 2005. Aplikasi analisis multivariate dengan program SPSS: Edisi Kedua. Semarang: Badan Penerbit Undip.

Kantor Koperasi dan UKM Kabupaten Bogor. 2007. Laporan perkembangan dana bergulir kabupaten Bogor.

Kementerian Koperasi dan Usaha Kecil dan Menengah Republik Indonesia. 2013. Statistik koperasi dan usaha kecil menengah. Jakarta: Kementerian Koperasi dan Usaha Kecil.

Kristiningsih, Trimarjono, Adrianto. 2014. Analisis faktor-faktor yang mempengaruhi perkembangan usaha kecil menengah (Studi Kasus pada UKM di Wilayah Surabaya), The 7th NCFB and Doctoral Colloquium 2014, towards a new Indonesia business architecture, sub tema: "business and economic transformation towards AEC 2015", Fakultas Bisnis dan Pascasarjana UKWMS hal:141-154.

Kurnia, Dadang; Hermawa, Tedy Maulana. 2014. Analisis produktivitas kerja dengan metode OMAX di PT. Tegar Metalindo Lestari. Jurnal Ilmiah dan Teknologi,
Volume 10, Nomor 28, Oktober 2014, Hal 1-17.

Peraturan Menteri Negara Koperasi dan UKM Nomor 06/Per/M.KUKM/I/2007 tentang Pedoman Teknis Perkuatan Permodalan Koperasi dan Usaha Mikro dalam rangka Program P3KUM Pola Syariah

Peraturan Menteri Negara Koperasi dan UKM Nomor 08/Per/M.KUKM/II/2007 tentang pedoman teknis perkuatan permodalan koperasi dan usaha mikro dalam rangka program P3KUM pola konvensional.

Qodri. 2006. Analisis strategi pengembangan usaha kecil dalam pemberdayaan ekonomi rakyat (studi kasus usaha kerajinan kain tapis di Bandar Lampung). Tesis Program Pascasarjana MPKP Fakultas Ekonomi Universitas Indonesia.

Rifa'I, Bachtiar. 2013. Efektivitas pemberdayaan usaha mikro kecil dan menengah (UMKM) krupuk ikan dalam program pengembangan labsite pemberdayaan masyarakat Kedung Rejo Kecamatan Jabon Kabupaten Sidoharjo. Jurnal Kebijakan dan Manajemen Publik, volume 1, Nomor 1, Januari 2013 Halaman 130-136.

Saragih, Jhon Bernando. 2003. Dampak implementasi program kemitraan usaha terhadap perkembangan usaha kecil di DKI Jakarta studi kasus di perkampungan Industri Kecil/PIK Pulogadung-Kakarta Timur. Tesis MPKP UI, Jakarta.

Sasono, Adi. 2001. Pemberdayaan ekonomi kerakyatan. Jakarta: Penerbit Center for Information and Development Studies (CIDES),

Sugiyono. 2011. Metode penelitian bisnis. Semarang: Alfabetha.

Sutopo, Wahyu. 2004. Analisis hubungan antara lembaga keuangan mikro dan kontribusi usaha kecil menengah dalam pengentasan kemiskinan di Indonesia, Tesis. Program Pascasarjana Ilmu Manajemen Fakultas Ekonomi Universitas Indonesia.

Syarif, Teuku; d Etty. 2009. Kajian kontribusi kredit bantuan perkuatan dalam mendukung permodalan UMKM, Jurnal Peng- 
Jurnal Ekonomi Pembangunan, 16 (1), Juni 2015, 85-101

kajian Koperasi dan UKM, Volume 4 Agustus 2009, hal: 62-87.

Yovani, Nadia. 2001. Analisis kemampuan bersaing sentra usaha kecil furniture kayu. Tesis MPKP. Universitas Indonesia, Jakarta.

Yulinar. 2007. Analisis faktor-faktor pendorong pertumbuhan usaha kecil menengah di Provinsi Lampung, Tesis Program Pascasarjana Ilmu Ekonomi Fakultas Ekonomi Universitas Indonesia. 